\title{
THE EVALUATION OF FINANCIAL PERFORMANCES OF LOGISTICS COMPANIES IN TURKEY: A DATA ENVELOP- MENT ANALYSIS APPROACH ${ }^{1}$
}

\author{
Elgün ALIYEV² \& Merve ERTOK ONURLU³
}

\begin{abstract}
In this study, the financial performance of 10 logistics companies operating in the storage, transport and logistics services sector in Turkey is evaluated for years from 2011 to 2017 by using the Data Envelopment Analysis (DEA) method. In accordance with the purpose of this study, the input variables are selected as total assets, equity and number of employees whereas the output variables are net sales, profit before interest and tax and amount of exports. In measuring the financial performances of firms listed in the data set, the Charnes, Cooper, Rhodes (CCR) model based on the assumption of constant returns to scale and the Banker, Charnes, Cooper (BCC) model based on the assumption of variable return to scale are employed in the input-oriented DEA model. As a result of our study, efficient and ineffective logistics companies are identified for years from 2011 to 2017. The reference sets for ineffective companies are determined, and the extent to which ineffective companies should improve according to the companies they refer to is determined. The results of DEA CCR-I model suggests that 2015 has the highest number of active companies (7). The year in which the average efficiency scores of the companies is the highest (89.2\%) is 2016. According to the DEA BCC-I model, 2015 is associated with the largest number of active firms (9) and the average productivity scores of these firms are the highest (99.1\%) in that particular year.
\end{abstract}

Keywords: Logistics, Firm Performance, Data Envelopment Analysis, Linear Programming.

JEL Codes: C44, C67, L25.

Başvuru: 08.02.2021 Kabul: 01.05.2021

1 Bu çalışma, Çanakkale Onsekiz Mart Üniversitesi, Lisansüstü Eğitim Enstitüsü, Uluslararası Ticaret ve Lojistik Anabilim Dalında, Dr. Öğr. Üyesi Merve ERTOK ONURLU'nun danışmanlığında yürütülen Elgün ALIYEV'in 2020 yılında tamamlanan, "Türkiye'deki Lojistik Firmaların Finansal Performanslarının Veri Zarflama Analizi ve Malmquist Toplam Faktör Verimlilik Endeksine Göre Değerlendirilmesi” başlıklı Yüksek Lisans tezinden faydalanılarak üretilmiştir. Araştırma ve Yayın Etiğine uygun olarak hazırlanmıştır.

2 Çanakkale Onsekiz Mart Üniversitesi, Lisansüstü Eğitim Enstitüsü, Uluslararası Ticaret ve Lojistik Bölümü, Çanakkale, Türkiye, elgunaliyev50@gmail.com, https://orcid.org/0000-0001-6556-9829

3 Dr. Öğr. Üyesi, Çanakkale Onsekiz Mart Üniversitesi, Biga İktisadi ve İdari Bilimler Fakültesi, Ekonometri Bölümü, Çanakkale, Türkiye, m.ertok.onurlu@comu.edu.tr, https://orcid.org/0000-0001-5187-1568 


\section{TÜRKIYE'DEKİ LOJISTIKK FİRMLARIN FINANSAL PERFORMANSLARININ DEĞERLENDİRILMESİ: VERİ ZARFLAMA ANALIZII YAKLAŞIMI ${ }^{4}$}

Öz

Bu çalışmada, Veri Zarflama Analizi (VZA) yönteminden yararlanılarak, Türkiye'de Depolama, Taşımacılık ve Lojistik hizmetler sektöründe faaliyet gösteren 10 lojistik firmanın 2011-2017 yılları için finansal performans değerlendirilmesi yapılmıştır. Çalışmanın amacına uygun olarak, girdi değişkenleri toplam aktif, öz kaynaklar, çalışan sayısl; çıktı değiş̧kenleri ise net satışlar, faiz ve vergi öncesi kâr (FVÖK), ihracat miktarı değişkenlerinden oluşturulmuştur. Oluşturulmuş girdi-çıktı değişkenlerine yönelik verilerin ölçülmesinde, girdi yönlü VZA modeli kullanılarak, hem ölçeğe göre sabit getiri varsayımına dayanan Charnes, Cooper, Rhodes (CCR) modeli, hem de ölçeğe göre değişken getiri varsayımına dayanan Banker, Charnes, Cooper (BCC) modelleri kullanılmıştır. Çalışma sonucunda 2011-2017 yıllarında etkin ve etkin olmayan lojistik firmalar tespit edilmiş, etkin olmayan firmalar için referans kümeleri belirlenerek, etkin olmayan firmaların referans aldıklarl firmalara göre yoğunluk değerlerinden yararlanılarak hangi oranda iyileştirme yapmaları gerektiği tespit edilmiştir. Elde edilen bulgular incelendiğinde, VZA CCR-I modelinin sonuçlarına göre, 2015 yılı en fazla aktif firmaya sahiptir (7). Firmaların ortalama verimlilik puanlarının en yüksek olduğu yıl (\%89.2) 2016'dır. VZA BCC-I modeline göre ise en fazla sayıda aktif firmanın (9) bulunduğu ve bu firmaların ortalama verimlilik puanlarının en yüksek olduğu yıl $2015^{\prime}$ tir (\%99.1).

Anahtar Kelimeler: Lojistik, Firma Performansl, Veri Zarflama Analizi, Doğrusal Programlama.

JEL Kodları: C44, C67, L25.

"Bu çalışma Araştırma ve Yayın Etiğine uygun olarak hazırlanmıştır."

\section{INTRODUCTION}

In today's global world where high competition conditions prevail, companies have to use their social, human and financial resources efficiently without wasting them. In the developing world economy, companies need to improve themselves in line with the developing technology and achieve financial success in order to increase their competitiveness levels towards increasing demands.

Financial performance measurement for firms is crucial in the sense that firms would like to know more about their activities in which they participate. They would like to determine the

4 Genişletilmiş Türkçe Özet, İngilizce makalenin aşağısında yer almaktadır. 
level of financial success and learn whether the firm's goals are realized and achieved. As a result, the firm's plans can be accurately determined.

It is possible to suggest that many companies set similar goals, such as more efficiency, more customer focus, more flexibility, and improvements in processes by reducing costs. If companies cannot measure to what extent the targets are achieved, the realization of these targets becomes difficult. Performance measurement is important for companies which aim to achieve competitive advantage and differentiation. However, during this process they may need a tool that should be simple, continuous and efficient for successful performance measurement (Alfaro et al., 2007: 641). In general, we can see that companies around the world are at similar levels in terms of both production costs and quality. For this reason, improvements are required in logistics activities in order for companies to gain competitive advantage over other companies. Turkey has an important place in the world with its strategic position. The young population in the country and recent investments in the logistics sector can be assumed as a surplus. The importance of the logistics sector, which is one of the main service sectors in the economy is very important for the commercial and manufacturing activities within a country (Gökalp, 2014: 214). For this reason, it is crucial to evaluate the financial performance of companies in the logistics sector in Turkey.

In today's intense competitive environment, companies should make the best use of their existing resources and periodically carry out performance evaluation to see whether they have achieved the specified goals. In order to measure strategic performance among companies, companies operating in the same sector should be compared with each other according to objective performance indicators.

Performance is generally defined as a goal to be achieved within the framework of plans created for a predetermined purpose (Gencer, 2006: 6). Performance measurement reveals what goals an institution has, what the manpower potential is, the physical and financial resources in its possession, which methods and techniques are applied to those intended goals (Yeşilyurt, 2003: 15). Performance measurement is generally divided into 3 groups: a) ratio analysis, b) parametric methods and c) non-parametric methods (Baysal et al., 2004: 438).

Data Envolepment Analysis (DEA) is the most preferred technique among non-parametric performance measurement methods in recent years and was developed by Charnes et al. (1978) (Wheelock and Wilson, 1995: 42). DEA is a technique based on linear programming that measures the relative performance of decision units when there are more than one input-output along with different measurement units. The basic assumption in DEA is that all enterprises, whose effectiveness is measured, have similar strategic goals and the same type of output produced by using the same type of inputs (Oruç, 2008: 11). One of the most important features of DEA is to make the number of ineffective units in each decision-making unit measurable. With this feature, the method can show the data for the need to reduce input and/or increase the amount of output in cases where the units are not active (Yalçıner et al., 2004: 5). 
The main objective of our study is to investigate the financial performance of logistics companies operating in Turkey for years from 2011 to 2017 and to make comparisons between these companies according to their activity levels. The efficiency levels of the logistics ompanies are determined by the Data Envelopment Analysis Approach. If one company is found to be ineffective, we further explain how such companies can improve by creating a reference set. Ineffective DMUs are made effective using active units in the reference set.

To the best our knowledge, this is the first study which intends to make a contribution to the existing literature by investigating the financial performances of logistics companies operating in Turkey using a quantitative approach.

\subsection{Literature Review}

In terms of performance measurement, there exists a variety of studies, which employs the DEA method in the literature. We can list some of these studies as below.

Chandra, Cooper, Li and Rahman (1998) carried out a financial performance analysis of 29 textile companies operating in Canada in 1994 by DEA method. They used CCR as DEA model in their studies. They concluded that a total of 8 companies are effective. It was suggested that ineffective companies need to make serious improvements in their firm structure, strategies and capacity plans in order to operate effectively. Minwir Al-Shammari (1999) measured the efficiency of 55 companies in the manufacturing industry operating in the Amman Finance Exchange in Jordan in 1995. In the study, output direction BCC model was used. As a result, the number of effective firms was found to be 12, and the average efficiency score of these firms was $54.7 \%$.

A study by Bakırc1 (2006) examined 13 companies in the automotive industry in Turkey's financial activity and employed the DEA method. Both CCR and BCC models are employed in the study. He concluded that the small-scale companies are more effective than other companies. Similar to Bakırcı (2006), Ertuğrul and Işık (2008) carried out efficiency measurements based on the financial statements of 13 companies in the main metal industry between 2003-2007 using DEA method. They used CCR as DEA model in their studies. As a result, they found that 4 companies are effective in 2003 whereas only 1 company was effective in 2004. Moreover, they further suggested that 5 companies are effective in 2005, and a total of 2 companies are effective in 2006 and 2007.

Kaya, Öztürk and Özer (2010) made a performance comparison using the DEA method, using the financial statements of 25 companies in the Metalware, Machinery and Equipment Making sector for the 4 periods of 2008. The analysis was carried out using the output direction CCR DEA model. As a result, they suggested that a total of 5 companies are active in 4 periods. Another study by Cenger (2011) measures the efficiency of 12 companies in the 
cement sector using the financial statements for the period 1999-2003. He found that 9 of the companies are effective and the average efficiency value was $75 \%$.

\section{METHOD}

\subsection{Data Envelopment Analysis (DEA)}

In 1978, with the study of Charnes, Cooper and Rhodes (CCR) named "Measuring the Efficiency of Decision Making Units", the name of the DEA method became known and thereafter the activities of the state organizations that did not have the goal of making profit were measured by creating the first Data Envelopment Analysis model (Wheelock and Wilson, 1995: 42). In this article, Charnes et al. (1987) coined the term "Decision Making Unit" (DMU) to describe companies and departments whose production processes are homogeneous with each other into a common input and output whose efficiency will be measured (Köksal, 2001: 75).

By examining the input and output values for all DMUs using the DEA method, the ones with the best performance rating are selected and these DMUs create the effective limit. The values of the DMUs that are not in the effective limit are calculated according to their distance to the active units. The limit created by the highest production amounts that can be obtained with the least amount of input is the effective production limit. The name of this method is named DEA because the active DMUs that form the effective production limit surround the ineffective DMUs. All active or ineffective input-output conversions form the Production Possibility Set (PPS) (Oruç, 2008: 13).

As a result of the calculations obtained by DEA method, there exists an efficiency value between 0 and 1 or between 0 and 100 in \% for each DMU. Units with an efficiency value equal to $1(100 \%)$ are active units and the group formed by these active units is called the reference set. DMUs with efficiency values less than 1 are relatively inefficient. The rate of deviation of the ineffective DMUs from 1 shows the relative ineffectiveness (Aydemir, 2002: 89-90). The biggest benefit in applying the DEA method is the determination of strategies for inactive DMUs to perform effectively. The target in these strategies is usually the weighted average of the active units in the reference set of the inactive units. The calculations show that efficient units use an available technology. Therefore, the technology of active units is accepted as accessible for inefficient units (Depren, 2008: 28).

\subsection{Data Envelopment Analysis Models}

DEA models take the form of maximization or minimization of the objective function under the influence of certain constraints. The assumptions that are valid for linear programming 
to reach the efficiency level with the most accurate use of limited resources are also valid for DEA (Barutçu, 2013: 24). DEA models consist of 2 main models due to criterion differences. The first of these is the CCR-Input and CCR-Output models, which are obtained by the studies of Charnes, Cooper and Rhodes (CCR), operating under constant returns to scale, and have aspects for input and output. The other is the BCC-I and BCC-O model, developed under variable returns to scale, created by Banker, Charnes and Cooper (BCC) making differences in the first model (Paradi and Schaafnit, 2004: 721). In the focal point of input-oriented models, it is measured at what level the inputs should be minimized by the DMUs that are not effective at any output level. The main purpose of these models is to minimize the amount of input. In the models whose focus is on output, the aim is to measure at what level the outputs should be increased in order to ensure the efficiency of the ineffective DMUs at any input level. The main purpose of these models is to minimize the outputs (Bak1rc1, 2006: 141).

The CCR-I model is a model that reveals how much reduction should be made in the input composition in order to achieve this output level effectively without changing the output level (Oruç, 2008: 23). This model is explained as follows (Chen and Ali, 2002: 477);

$$
\mathrm{E}_{0}=\max \frac{\sum_{\mathrm{r}=1}^{\mathrm{s}} \mathrm{u}_{\mathrm{r}} \mathrm{y}_{\mathrm{ro}}}{\sum_{\mathrm{i}=1}^{\mathrm{m}} \mathrm{v}_{\mathrm{i}} \mathrm{x}_{\mathrm{io}}}
$$

s.t.

$$
\begin{array}{ll}
\frac{\sum_{\mathrm{r}=1}^{\mathrm{s}} \mathrm{u}_{\mathrm{r}} \mathrm{y}_{\mathrm{rj}}}{\sum_{\mathrm{i}=1}^{\mathrm{m}} \mathrm{v}_{\mathrm{i}} \mathrm{x}_{\mathrm{ij}}} \leq 1, \quad \mathrm{j}=1,2, \ldots . \mathrm{n} \\
v_{i} \geq 0, u_{r} \geq 0 & r=1,2, \ldots . . s \quad i=1,2, \ldots . . m
\end{array}
$$

Here,

$$
\begin{array}{llr}
\mathrm{n} & : \text { DMUs number } & \mathrm{j}=1,2, \ldots . \mathrm{n} \\
\mathrm{s} & : \text { Number of Outputs } & \mathrm{r}=1,2, \ldots . \mathrm{s} \\
\mathrm{m} & : \text { Number of Inputs } & \mathrm{i}=1,2, \ldots . \mathrm{m} \\
\mathrm{u}_{\mathrm{r}} & : \text { o. DMUs by r. weight value given to the output } \\
\mathrm{v}_{\mathrm{i}} & : \text { o. DMUs by i. weight value given to the input } \\
\mathrm{x}_{\mathrm{io}} & : \text { o. DMUs uses i. input amount } \\
\mathrm{y}_{\mathrm{ro}} & : \text { o. DMUs uses r. output amount } \\
\mathrm{x}_{\mathrm{ij}} & : \mathrm{j} . \text { DMUs uses i. input amount } \\
\mathrm{y}_{\mathrm{rj}} & : \mathrm{j} . \text { DMUs uses r. output amount } \\
778 &
\end{array}
$$


As the model described in Equation 1, it is obvious that the value of the objective function will not take a value above 1 as the fractional programming model. Once Equation 1 is solved, the weights () of the DMUs are obtained (Oruç, 2008: 24). It is possible to write the described fractional programming model according to the linear programming model as in Equation 2 (Sathye, 2003: 666);

$$
\begin{aligned}
E_{0}= & \max \sum_{r=1}^{s} u_{r} y_{r o} \\
\text { s.t. } & \sum_{i=1}^{m} v_{i} x_{i o}=1 \\
& \sum_{r=1}^{s} u_{r} y_{r j} \leq \sum_{i=1}^{m} v_{i} x_{i j} \quad j=1,2, \ldots \ldots n \\
& v_{i}, u_{r} \geq \varepsilon \quad \mathrm{r}=1,2, \ldots . . \mathrm{s} \quad \mathrm{i}=1,2, \ldots \ldots \mathrm{m}
\end{aligned}
$$

$\varepsilon \quad$ : A small enough number $\left(\varepsilon \leq 10^{-6}\right)$

The BCC model, which is an extension of the CCR model, was developed in 1984 by Banker Charnes and Cooper. BCC model is based on the assumption of variable return to scale as a characteristic feature (Paradi and Schaafnit, 2004: 721). The main difference that distinguishes the BCC model from the CCR model is that for each DMUs examined in the variable return assumption in terms of scale, the sum of the values 1 (the value that provides the information needed to create the possible effective input and output composition) is equal to 1 for the decision point that does not reach the effective limit obtained as a result of linear programming (Dinçer, 2008: 834).

As in the input-oriented CCR model, this model is also a model that sets out how much reduction should be made in the input composition in order to achieve this output level effectively without making a change in the output level.

This model is explained as below (input oriented) (Kaynar, 2004: 69):

$$
\mathrm{E}_{0}=\max \frac{\sum_{\mathrm{r}=1}^{\mathrm{s}} \mathrm{u}_{\mathrm{r}} \mathrm{y}_{\mathrm{ro}}-u_{\mathrm{o}}}{\sum_{\mathrm{i}=1}^{\mathrm{m}} \mathrm{v}_{\mathrm{i}} \mathrm{x}_{\mathrm{io}}}
$$

s.t.

$$
\begin{aligned}
& \frac{\sum_{r=1}^{s} u_{r} y_{r j}-u_{o}}{\sum_{i=1}^{m} v_{i} x_{i j}} \leq 1, \quad j=1,2, \ldots . . n \\
& v_{i} \geq \varepsilon, u_{r} \geq \varepsilon \quad r=1,2, \ldots . s \quad i=1,2, \ldots . m
\end{aligned}
$$


This model, which is in the fractional programming model, can be written according to the linear programming model as in the Equation 4.

$$
\begin{aligned}
E_{0}= & \max \sum_{r=1}^{s} u_{r} y_{r o}-u_{o} \\
& \text { s.t. } \\
& \sum_{i=1}^{m} v_{i} x_{i o}=1 \\
& \sum_{r=1}^{s} u_{r} y_{r j}-u_{o} \leq \sum_{i=1}^{m} v_{i} x_{i j} \quad j=1,2, \ldots, n \\
v_{i}, u_{r} \geq \varepsilon & r=1,2, \ldots \ldots, s \quad i=1,2, \ldots, m
\end{aligned}
$$

DEA first aimed to measure efficiency by comparing non-profit organizations. In later times, it has become widely used in research and development projects, in measuring the relative performance of multi-branch companies and in comparative measurement of relative effectiveness of companies involved in the production and service sector for profit (Yalçıner et al., 2004: 5).

\section{RESULTS}

The study is included in the company to obtain the data of the input-output variables, Turkey has benefited from Fortune 500 magazine's official website. In the study, it is aimed to interpret the performance of the companies in a better way by using data from more than one year. For this reason, by not including only one year's data in the study, the relevant input-output data can be accessed between 2011 and 2017, by including 10 companies that produce similar outputs in the Storage, Transport and Logistics services sector and have a homogeneous structure, and logistics companies whose financial data cannot be reached for these years excluded from the scope of the study.

\subsection{Determination of Decision Making Units}

In this section, 10 Logistics companies, whose financial data are obtained for 2011, 2012, 2013, 2014, 2015, 2016, 2017, operating in the Storage, Transportation and Logistics services sector, are discussed. These companies, which are shown as decision-making units, are listed in Table 1. 
Table 1: Decision Making Units Used In the Study 5

\begin{tabular}{ll}
\hline No & \multicolumn{1}{c}{ Logistics Companies } \\
\hline $\mathbf{1}$ & Ekol Logistics Inc. \\
\hline $\mathbf{2}$ & Turistik Air Transport Inc. \\
\hline $\mathbf{3}$ & Mersin International Port Management Inc. \\
\hline $\mathbf{4}$ & Horoz Logistics Inc. \\
\hline $\mathbf{5}$ & Alışan International Transport and Trade Inc. \\
\hline $\mathbf{6}$ & Reysaş Transportation and Logistics Trade Inc. \\
\hline $\mathbf{7}$ & Netlog Logistics Services Inc. \\
\hline $\mathbf{8}$ & Borusan Logistics Inc. \\
\hline $\mathbf{9}$ & Mars International Transport and Trade Inc. \\
\hline $\mathbf{1 0}$ & Omsan Logistics Inc. \\
\hline
\end{tabular}

\subsection{Determination of Input-Output Variables}

The selection of appropriate input-output variables is important for companies to make the right decisions as a result of the analysis. Although there are different opinions in the selection of input and output variables in the literature regarding the measurement of firm efficiency, it should be taken into consideration which size of firms will be measured in the selection of variables. In determining the mentioned input-output variables, the financial efficiency measurement studies in the literature are taken into consideration in accordance with the availability of the data. The input and output variables used in the study are shown in Table 2.

Table 2: Input and Output Variables Used in the Study

\begin{tabular}{lc}
\hline \multicolumn{1}{c}{ Input Variables } & Output Variables \\
\hline Total Assets & Net Sales \\
\hline Equity & Profit Before İnterest And Tax \\
\hline Number Of Employees & Amount Of Exports \\
\hline
\end{tabular}

\subsection{Efficiency Scores of Companies}

Within the scope of the research, the financial activities of logistics companies are obtained by DEA method between 2011-2017. In the analysis, the efficiency values of the companies

5 The data was obtained from Fortune Magazine's official website and arranged in accordance with the purpose of the study. (www.fortuneturkey.com/fortune500). 
are determined according to the established CCR-I and BCC-I model, the summary of DEA CCR-I efficiency scores is shown in Table 3, and the summary of DEA BCC-I efficiency scores are shown in Table 11.

The data envelopment analysis model is used to measure firm performances using the DEAP 2.1 package program developed by Coelli (1996).

Table 3: Efficiency Scores of Companies According to CCR-I Model in 2011-2017

\begin{tabular}{|c|c|c|c|c|c|c|c|}
\hline \multirow{2}{*}{$\begin{array}{c}\text { Firm } \\
\text { No }\end{array}$} & \multicolumn{7}{|c|}{ Efficiency Score } \\
\hline & 2011 & 2012 & 2013 & 2014 & 2015 & 2016 & 2017 \\
\hline 1 & $24,6 \%$ & $41,1 \%$ & $23,7 \%$ & $28,7 \%$ & $40,9 \%$ & $33,7 \%$ & $29,2 \%$ \\
\hline 2 & $100,0 \%$ & $100,0 \%$ & $100,0 \%$ & $100,0 \%$ & $100,0 \%$ & $100,0 \%$ & $100,0 \%$ \\
\hline 3 & $100,0 \%$ & $96,8 \%$ & $77,3 \%$ & $100,0 \%$ & $100,0 \%$ & $100,0 \%$ & $100,0 \%$ \\
\hline 4 & $100,0 \%$ & $100,0 \%$ & $100,0 \%$ & $100,0 \%$ & $100,0 \%$ & $84,4 \%$ & $77,9 \%$ \\
\hline 5 & $37,1 \%$ & $62,6 \%$ & $46,5 \%$ & $45,4 \%$ & $100,0 \%$ & $100,0 \%$ & $91,6 \%$ \\
\hline 6 & $96,7 \%$ & $100,0 \%$ & $100,0 \%$ & $100,0 \%$ & $100,0 \%$ & $100,0 \%$ & $100,0 \%$ \\
\hline 7 & $75,9 \%$ & $100,0 \%$ & $39,9 \%$ & $38,2 \%$ & $62,4 \%$ & $86,2 \%$ & $100,0 \%$ \\
\hline 8 & $53,7 \%$ & $100,0 \%$ & $69,7 \%$ & $55,4 \%$ & $100,0 \%$ & $100,0 \%$ & $56,2 \%$ \\
\hline 9 & $100,0 \%$ & $100,0 \%$ & $94,9 \%$ & $100,0 \%$ & $100,0 \%$ & $100,0 \%$ & $95,3 \%$ \\
\hline 10 & $69,7 \%$ & $72,6 \%$ & $49,6 \%$ & $69,3 \%$ & $88,1 \%$ & $88,1 \%$ & $61,8 \%$ \\
\hline Mean. & $75,8 \%$ & $87,3 \%$ & $70,2 \%$ & $73,7 \%$ & $89,1 \%$ & $89,2 \%$ & $81,2 \%$ \\
\hline
\end{tabular}

Analysis results are reported in Table 3. According to the CCR-I DEA model, 4 out of 10 companies examined in 2011 are effective. Effective companies are Turistik Air Transport, Mersin International Port Management, Horoz Logistics and Mars Logistics. The company with the lowest performance rating is Ekol Logistics with an efficiency score of $24.6 \%$. The average efficiency score of companies in 2011 is calculated as $75.8 \%$. 
Table 4: Reference Sets and Density Values of Ineffective DMUs According to 2011 CCR-I Model

\begin{tabular}{ccc}
\hline Ineffective DMUs & Reference Sets & Density Values \\
\hline 1 & $4 ; 2$ & 0,$129 ; 1,192$ \\
\hline 5 & $9 ; 4 ; 2 ; 3$ & 0,$001 ; 0,228 ; 0,256 ; 0,018$ \\
\hline 6 & $2 ; 9 ; 3$ & 4,$541 ; 0,738 ; 0,046$ \\
\hline 7 & $2 ; 4$ & 1,$795 ; 0,10$ \\
\hline 8 & $2 ; 4$ & 1,$795 ; 0,10$ \\
\hline 10 & $3 ; 2 ; 4 ; 9$ & 0,$006 ; 0,261 ; 0,277 ; 1,054$ \\
\hline
\end{tabular}

In Table 4, reference sets have been created for 6 ineffective companies and their improvement degrees are shown. Ekol Logistics, the company with the lowest performance rating, should refer to Horoz Logistics and Turistik Air Transport companies shown in Table 4 with 4, 2. In order for Ekol Logistics to make its efficiency score $100 \%$, it is required to make $12.9 \%$ improvement according to Horoz Logistics and 119\% according to Turistik Air Transport company.

In Table 3, the effective number of firms according to CCR-I model in 2012 is 6 and these are Turistik Air Transport, Horoz Logistics, Reysaş Logistics, Netlog Logistics, Borusan Logistics and Mars Logistics. The company with the lowest performance rating is Ekol Logistics with an efficiency score of $41.1 \%$. The average efficiency score of companies in 2012 is calculated as $87.3 \%$.

Table 5: Reference Sets and Density Values of Ineffective DMUs According to 2012 CCR-I Model

\begin{tabular}{ccc}
\hline Ineffective DMUs & Reference Sets & Density Values \\
\hline 1 & $4 ; 8 ; 2$ & 0,$068 ; 0,094 ; 1,679$ \\
\hline 3 & $6 ; 8$ & 1,$006 ; 1,422$ \\
\hline 5 & $4 ; 2 ; 8$ & 0,$254 ; 0,137 ; 0,137$ \\
\hline 10 & $4 ; 2 ; 8 ; 6$ & 0,$436 ; 0,227 ; 0,404 ; 0,047$ \\
\hline
\end{tabular}

The companies that should refer to Ekol Logistics, the company with the lowest performance rating in Table 5, are Horoz Logistics, Borusan Logistics and Turistik Air Transport companies shown with $4,8,2$. In order for the company to reach $100 \%$ efficiency score, it should make an improvement of $6.8 \%$ according to Horoz Logistics, 9.4\% according to Borusan Logistics, and 167\% according to the Turistik Air Transport company.

In Table 3, the number of active companies is 3 in 2013 according to the CCR-I model. These are Turistik Air Transport, Horoz Logistics, Reysaş Logistics companies. The company with 
the lowest performance rating is Ekol Logistics with an efficiency score of $23.7 \%$. In 2013, the average efficiency score of companies is found to be $70.2 \%$.

Table 6: Reference Sets and Density Values of Ineffective DMUs According to 2013 CCR-I Model

\begin{tabular}{ccc}
\hline Ineffective DMUs & Reference Sets & Density Values \\
\hline 1 & $2 ; 4$ & 1,$450 ; 0,494$ \\
\hline 3 & $6 ; 4$ & 0,$275 ; 0,877$ \\
\hline 5 & $4 ; 2$ & 0,$143 ; 0,507$ \\
\hline 7 & $2 ; 4$ & 1,$065 ; 0,850$ \\
\hline 8 & $2 ; 4 ; 6$ & 2,$092 ; 0,062 ; 0,321$ \\
\hline 10 & $6 ; 4 ; 2$ & 0,$181 ; 0,549 ; 0,383$ \\
\hline
\end{tabular}

Ekol Logistics, the company with the lowest performance rating, should refer to the Turistik Air Transport and Horoz Logistics Company shown in Table 6 with 2, 4. In order for the company to reach $100 \%$ efficiency score, it should make an improvement of $145 \%$ according to the Turistik Air Transport company and 49.4\% according to the Horoz Logistics company.

According to Table 3, the number of active companies is 5 according to CCR-I model in 2014, and these are Turistik Air Transport, Mersin International Port Management, Horoz Logistics, Reysaş Logistics and Mars Logistics companies. The company with the lowest performance rating is Ekol Logistics with an efficiency score of 28.7\%. In 2014, the average efficiency score of companies is found to be $73.7 \%$.

Table 7: Reference Sets and Density Values of Ineffective DMUs According to 2014 CCR-I Model

\begin{tabular}{ccc}
\hline Ineffective DMUs & Reference Sets & Density Values \\
\hline 1 & $4 ; 9 ; 2$ & 0,$976 ; 0,078 ; 0,973$ \\
\hline 5 & $4 ; 2$ & 0,$114 ; 0,448$ \\
\hline 7 & $2 ; 9 ; 4$ & 1,$079 ; 0,26 ; 1,802$ \\
\hline 8 & $6 ; 2$ & 0,$219 ; 1,816$ \\
\hline 10 & $9 ; 2 ; 3$ & 0,$220 ; 0,615 ; 0,153$ \\
\hline
\end{tabular}

According to Table 7, Ekol Logistics, the company with the lowest performance rating, should refer to Horoz Logistics, Mars International Transport and Turistik Air Transport companies shown with $4,9,2$. In order for the company to reach a $100 \%$ efficiency score, it should make an improvement of $97.6 \%$ according to Horoz Logistics, $7.8 \%$ according to Mars International Transport company, and 97.3\% according to Turistik Air Transport. 
According to Table 3, there is an increase in the number of active companies in 2015 and the number of active companies increased to 7, and these companies are Turistik Air Transport, Mersin International Port Management, Horoz Logistics, Alışan International Transport, Reysaş Logistics, Borusan Logistics and Mars Logistics. The company with the lowest performance rating is Ekol Logistics with an efficiency score of 40.9\%. In 2015, the average efficiency score of companies is found to be $89.1 \%$.

Table 8: Reference Sets and Density Values of Ineffective DMUs According to 2015 CCR-I Model

\begin{tabular}{ccc}
\hline Ineffective DMUs & Reference Sets & Density Values \\
\hline 1 & $9 ; 2 ; 4$ & 0,$120 ; 0,793 ; 1,602$ \\
\hline 7 & $4 ; 2 ; 9 ; 5$ & 0,$281 ; 1,155 ; 0,041 ; 1,667$ \\
\hline 10 & 9 & 1,190 \\
\hline
\end{tabular}

Ekol Logistics, the company with the lowest performance rating, should refer to Mars International Transport, Turistik Air Transport and Horoz Logistics, shown in Table 8 with 9, $2,4$. In order for the company to reach $100 \%$ efficiency score, it should make an improvement of $160 \%$ according to Horoz Logistics, 12\% according to Mars International Transport company, and $79 \%$ according to the Turistik Air Transport company.

According to Table 3, the number of companies that are active in 2016 is 6 and these companies are Turistik Air Transport, Mersin International Port Management, Alışan International Transport, Reysaş Logistics, Borusan Logistics and Mars International Transport. The company with the lowest performance rating is Ekol Logistics with an efficiency score of $33.7 \%$. In 2016, companies have the highest average efficiency score of $89.2 \%$ compared to other years.

Table 9: Reference Sets and Density Values of Ineffective DMUs According to 2016 CCR-I Model

\begin{tabular}{ccc}
\hline Ineffective DMUs & Reference Sets & Density Values \\
\hline 1 & $2 ; 5$ & 3,$152 ; 0,091$ \\
\hline 4 & $9 ; 6 ; 2$ & 0,$069 ; 0,036 ; 1,182$ \\
\hline 7 & $5 ; 2$ & 1,$194 ; 4,098$ \\
\hline 10 & $2 ; 9$ & 0,$119 ; 0,867$ \\
\hline
\end{tabular}

Ekol Logistics, the company with the lowest performance rating, should refer to the Turistik Air Transport and Alışan International Transport companies shown in Table 9 with 2, 5. In order for the company to reach a $100 \%$ efficiency score, it should make an improvement of 315\% according to the Turistik Air Transport company and 9.1\% according to the Alışan International Transport company. 
According to Table 3, the number of companies active in 2017 is 4, and these companies are Turistik Air Transport, Mersin International Port Management, Reysaş Logistics and Netlog Logistics. The company with the lowest performance rating is Ekol Logistics with an efficiency score of $29.2 \%$. In 2017 , the average efficiency score of companies is found to be $81.2 \%$.

Table 10: Reference Sets and Density Values of Ineffective DMUs According to 2017 CCR-I Model

\begin{tabular}{ccc}
\hline Ineffective DMUs & Reference Sets & Density Values \\
\hline 1 & $7 ; 2$ & 0,$032 ; 2,884$ \\
\hline 4 & $3 ; 2$ & 0,$053 ; 0,715$ \\
\hline 5 & $3 ; 7 ; 2$ & 0,$020 ; 0,066 ; 0,345$ \\
\hline 8 & $3 ; 2$ & 0,$257 ; 2,222$ \\
\hline 9 & $3 ; 2$ & 0,$221 ; 1,013$ \\
\hline 10 & $3 ; 2$ & 0,$102 ; 1,085$ \\
\hline
\end{tabular}

Ekol Logistics, the company with the lowest performance rating, should refer to the Turistik Air Transport and Netlog Logistics companies shown in Table 10 with 7, 2. In order for the company to reach $100 \%$ efficiency score, it should make an improvement of $288 \%$ according to the Turistik Air Transport company and 3.2\% according to the Netlog Logistics company.

It is seen that the Turistik Air Transport company is at a stable level of activity in the period 2011-2017.

Table 11: Efficiency Scores of Companies According to BCC-I Model in 2011-2017

\begin{tabular}{|c|c|c|c|c|c|c|c|}
\hline \multirow{2}{*}{$\begin{array}{c}\text { Firm } \\
\text { No }\end{array}$} & \multicolumn{7}{|c|}{ Efficiency Score } \\
\hline & 2011 & 2012 & 2013 & 2014 & 2015 & 2016 & 2017 \\
\hline 1 & $49,3 \%$ & $64,1 \%$ & $66,7 \%$ & $90,0 \%$ & $90,6 \%$ & $100,0 \%$ & $100,0 \%$ \\
\hline 2 & $100,0 \%$ & $100,0 \%$ & $100,0 \%$ & $100,0 \%$ & $100,0 \%$ & $100,0 \%$ & $100,0 \%$ \\
\hline 3 & $100,0 \%$ & $100,0 \%$ & $100,0 \%$ & $100,0 \%$ & $100,0 \%$ & $100,0 \%$ & $100,0 \%$ \\
\hline 4 & $100,0 \%$ & $100,0 \%$ & $100,0 \%$ & $100,0 \%$ & $100,0 \%$ & $88,4 \%$ & $85,6 \%$ \\
\hline 5 & $51,5 \%$ & $77,8 \%$ & $71,6 \%$ & $80,7 \%$ & $100,0 \%$ & $100,0 \%$ & $100,0 \%$ \\
\hline 6 & $100,0 \%$ & $100,0 \%$ & $100,0 \%$ & $100,0 \%$ & $100,0 \%$ & $100,0 \%$ & $100,0 \%$ \\
\hline 7 & $100,0 \%$ & $100,0 \%$ & $100,0 \%$ & $100,0 \%$ & $100,0 \%$ & $100,0 \%$ & $100,0 \%$ \\
\hline 8 & $100,0 \%$ & $100,0 \%$ & $100,0 \%$ & $100,0 \%$ & $100,0 \%$ & $100,0 \%$ & $100,0 \%$ \\
\hline 9 & $100,0 \%$ & $100,0 \%$ & $100,0 \%$ & $100,0 \%$ & $100,0 \%$ & $100,0 \%$ & $100,0 \%$ \\
\hline 10 & $100,0 \%$ & $82,8 \%$ & $68,0 \%$ & $69,5 \%$ & $100,0 \%$ & $88,1 \%$ & $65,9 \%$ \\
\hline Mean. & $90,1 \%$ & $92,5 \%$ & $90,6 \%$ & $94,0 \%$ & $99,1 \%$ & $97,7 \%$ & $95,2 \%$ \\
\hline
\end{tabular}


As a result of the analysis, in Table 11, companies active in 2011 according to the BCC-I model; It is understood that Reysaş Logistics, Netlog Logistics, Borusan Logistics and Omsan Logistics companies are included in the companies active in 2011 according to the CCR-I model. The company with the lowest performance grade is Ekol Logistics with an efficiency score of $49.3 \%$. In 2011, the BCC-I average efficiency score of companies is found to be $90.1 \%$.

Table 12: Reference Sets and Density Values of Ineffective DMUs According to 2011 BCC-I Model

\begin{tabular}{ccc}
\hline Ineffective DMUs & Reference Sets & Density Values \\
\hline 1 & $7 ; 2 ; 8 ; 4$ & 0,$119 ; 0,195 ; 0,079 ; 0,607$ \\
\hline 5 & $4 ; 2$ & 0,$250 ; 0,750$ \\
\hline
\end{tabular}

According to Table 12, Ekol Logistics, the company with the lowest performance rating, should refer to the companies shown in 7, 2, 8, 4 as Turistik Air Transport, Netlog Logistics, Borusan Logistics and Horoz Logistics. In order for the company to reach $100 \%$ efficiency score, it should make an improvement of $11.9 \%$ according to the Turistik Air Transport company, $19.5 \%$ according to the Netlog Logistics company, 7.9\% according to Borusan Logistics and $60.7 \%$ according to the Horoz Logistics company.

In Table 11, companies active according to 2012 BCC-I model; It is understood that Mersin International Port Management company is included in the companies active in 2012 according to the CCR-I model. The company with the lowest performance grade is Ekol Logistics with an efficiency score of $64.1 \%$. In 2012, the BCC-I average efficiency score of companies is found to be $92.5 \%$.

Table 13: Reference Sets and Density Values of Ineffective DMUs According to 2012 BCC-I Model

\begin{tabular}{ccc}
\hline Ineffective DMUs & Reference Sets & Density Values \\
\hline 1 & $7 ; 8 ; 4 ; 2$ & 0,$219 ; 0,147 ; 0,567 ; 0,066$ \\
\hline 5 & $2 ; 9 ; 8 ; 6$ & 0,$673 ; 0,165 ; 0,137 ; 0,026$ \\
\hline 10 & $4 ; 7 ; 8 ; 2$ & 0,$272 ; 0,092 ; 0,523 ; 0,114$ \\
\hline
\end{tabular}

According to Table 13, Ekol Logistics, which has the lowest performance rating, should refer to the companies that should be taken as reference by Turistik Air Transport, Netlog Logistics, Borusan Logistics and Horoz Logistics, which are shown with 7, 8, 4, 2. In order for the company to reach $100 \%$ efficiency score, it should make an improvement of $6.6 \%$ according to the Turistik Air Transport company, 21.9\% according to the Netlog Logistics company, $14.7 \%$ according to Borusan Logistics and 56.7\% according to the Horoz Logistics company.

The companies active according to the BCC-I model of 2013 in Table 11; It is understood that Mersin International Port Management, Netlog Logistics, Borusan Logistics and Mars 
International Transport companies are included in the companies that are active according to the CCR-I model in 2013. The company with the lowest performance rating is Ekol Logistics with an efficiency score of $66.7 \%$. In 2013, the BCC-I average efficiency score of companies is found to be $90.6 \%$.

Table 14: Reference Sets and Density Values of Ineffective DMUs According to 2013 BCC-I Model

\begin{tabular}{ccc}
\hline Ineffective DMUs & Reference Sets & Density Values \\
\hline 1 & $7 ; 8 ; 4$ & 0,$691 ; 0,120 ; 0,189$ \\
\hline 5 & $2 ; 4$ & 0,$780 ; 0,220$ \\
\hline 10 & $4 ; 8 ; 2$ & 0,$211 ; 0,288 ; 0,501$ \\
\hline
\end{tabular}

According to Table 14, Ekol Logistics, the company with the lowest performance rating, should refer to Netlog Logistics, Borusan Logistics and Horoz Logistics, shown with 7, 8, 4. In order for the company to reach $100 \%$ efficiency score, it should make an improvement of $69.1 \%$ according to Netlog Logistics, $12 \%$ according to Borusan Logistics, and $18.9 \%$ according to Horoz Logistics.

In Table 11, companies active according to the BCC-I model of 2014; It is understood that Netlog Logistics and Borusan Logistics companies are included in the companies active in 2014 according to the CCR-I model. The company with the lowest performance rating is Omsan Logistics with an efficiency score of 69.5\%. In 2014, companies BCC-I average efficiency score is found to be $94 \%$.

Table 15: Reference Sets and Density Values of Ineffective DMUs According to 2014 BCC-I Model

\begin{tabular}{ccc}
\hline Ineffective DMUs & Reference Sets & Density Values \\
\hline 1 & $8 ; 7 ; 2$ & 0,$099 ; 0,685 ; 0,217$ \\
\hline 5 & $4 ; 2$ & 0,$203 ; 0,797$ \\
\hline 10 & $2 ; 9 ; 3$ & 0,$634 ; 0,211 ; 0,154$ \\
\hline
\end{tabular}

According to Table 15, the companies that should refer to Omsan Logistics, which has the lowest performance rating, are Borusan Logistics, Netlog Logistics and Turistik Air Transport companies shown with $8,7,2$. In order for the company to reach $100 \%$ efficiency score, it should make an improvement of $9.9 \%$ according to Borusan Logistics, $68.5 \%$ according to Netlog Logistics, and $21.7 \%$ according to the Turistik Air Transport company.

In Table 11, active companies according to 2015 BCC-I; It is understood that Netlog Logistics and Omsan Logistics companies are included in the companies that are active in 2015 
according to the CCR-I model. Of the companies included in the analysis in 2015, only Ekol logistics firm performed lower than other companies with an efficiency score of $96.6 \%$. In 2015 , it is the year in which companies have the highest BCC-I average efficiency score with a value of $99.1 \%$ compared to other years.

Table 16: Reference Sets and Density Values of Ineffective DMUs According to 2015 BCC-I Model

\begin{tabular}{ccc}
\hline Ineffective DMUs & Reference Sets & Density Values \\
\hline 1 & $7 ; 8 ; 2$ & 0,$821 ; 0,138 ; 0,041$ \\
\hline
\end{tabular}

According to Table 16, Ekol Logistics, the company with the lowest performance rating, should refer to Borusan Logistics, Netlog Logistics and Turistik Air Transport companies shown with $7,8,2$. In order for the company to reach $100 \%$ efficiency score, it should make an improvement of $13.8 \%$ according to Borusan Logistics, $82.1 \%$ according to Netlog Logistics, and $4.1 \%$ according to the Turistik Air Transport company.

In Table 11, the companies active according to the BCC-I model of 2016; It is understood that Ekol Logistics and Netlog Logistics companies are included in the companies that are active according to the CCR-I model in 2016. The company with the lowest performance grade is seen to be Omsan Logistics with an efficiency score of 88.1\%. In 2016, the BCC-I average efficiency score of companies is found to be $97.7 \%$.

Table 17: Reference Sets and Density Values of Ineffective DMUs According to 2016 BCC-I Model

\begin{tabular}{ccc}
\hline Ineffective DMUs & Reference Sets & Density Values \\
\hline 4 & $2 ; 9 ; 7 ; 3 ; 5$ & 0,$718 ; 0,098 ; 0,019 ; 0,005 ; 0,159$ \\
\hline 10 & $9 ; 2$ & 0,$863 ; 0,137$ \\
\hline
\end{tabular}

According to Table 17, Omsan Logistics, which has the lowest performance rating, should refer to Mars International Transport and Turistik Air Transport companies shown in 9, 2. In order for the company to reach $100 \%$ efficiency score, it should make an improvement of $86.3 \%$ according to Mars International Transport company and $13.7 \%$ according to the Turistik Air Transport company.

Companies active according to the BCC-I model of 2017 in Table 11; It is understood that Ekol Logistics, Alışan International Transport, Borusan Logistics and Mars International Transport companies are included in the companies active in 2017 according to the CCR-I model. The company with the lowest performance rating is Omsan Logistics with an efficiency score of $65.9 \%$. In 2017, the BCC-I average efficiency score of companies is found to be $95.2 \%$. 
Table 18: Reference Sets and Density Values of Ineffective DMUs According to 2017 BCC-I Model

\begin{tabular}{ccc}
\hline Ineffective DMUs & Reference Sets & Density Values \\
\hline 4 & $3 ; 2$ & 0,$050 ; 0,950$ \\
\hline 10 & $9 ; 2 ; 7$ & 0,$406 ; 0,543 ; 0,051$ \\
\hline
\end{tabular}

According to Table 18, Omsan Logistics, the company with the lowest performance rating, should refer to Mars International Transport and Turistik Air Transport and Netlog Logistics companies, shown with $9,2,7$. In order for the company to reach $100 \%$ efficiency score, it should make an improvement of $40.6 \%$ according to Mars International Transportation company, $54.3 \%$ according to the Turistik Air Transport company and 5.1\% according to the Netlog Logistics company.

Turistik Air Transport, Mersin International Port Management, Reysaş Logistics and Netlog Logistics companies are seen to be at a decisive level of activity in the 2011-2017 period.

\section{DISCUSSION}

In today's highly competitive environment, companies should evaluate their existing resources in the best way and perform performance evaluation studies at periodic intervals in order to see whether they have reached the determined targets. Financial performance measurement should be carried out in a realistic and accurate manner in order for company managers to set goals for financial performance, to make comparisons with financial performance levels compared to competitors, to identify areas that may cause problems within the company, and to set the right goals for the company to solve possible problems in the future.

Firm performance has an important share in the business world. In this case, companies will continue their activities in their sector according to their performance level or they will terminate their activities by not meeting the required competitive conditions.

In this study, the effectiveness analysis of logistics companies in Turkey is evaluated by using the 2011-2017 period financial data. The study included 10 logistics companies featured in the Turkish Fortune 500 magazine. In the study, efficiency measurement is performed with the DEA, which is a non-parametric performance measurement method, which allows more than one input-output variables, and can display DMUs efficiency values numerically.

According to the results of DEA CCR-I model, in 2011, the average effectiveness score of logistic companies is $75.8 \%$, the number of effective companies is 4 (40\%); in 2012 the average efficiency score is $87.3 \%$, the number of effective companies $6(60 \%)$. For 2013 , the average efficiency score is $70.2 \%$, there exist $3(30 \%)$ effective companies, For 2014, the average efficiency score is $73.7 \%$, there exist 5 (50\%) effective companies, For 2015, the average efficiency score is $89.1 \%$, there exist 7 (70\%) effective companies, For 2016, the 
average efficiency score is $89.2 \%$, there exist $6(60 \%)$ effective companies, For 2017 , the average efficiency score is $81.2 \%$, and there exist 4 (40\%) effective companies. The year 2015 has the highest number of active companies (7). The year in which the average efficiency scores of the companies is the highest $(89.2 \%)$ is 2016.

When the DEA BCC-I model is examined, one can see that the efficiency values of logistics companies from 2011 to 2017 are high in terms of both the number of effective companies and the average efficiency score according to the CCR-I model. According to DEA BCC-I model, the average efficiency score of logistics companies in 2011 is $90.1 \%$, the number of effective companies is 8 (80\%). For 2012 the average efficiency score is $92.5 \%$, the number of effective companies is 7 (70\%), For 2013 the average efficiency score is $90.6 \%$, the number of effective companies 7 (70\%),For 2014, the average efficiency score $94 \%$, the number of effective companies 7 (70\%), For 2015, the average efficiency score $99.1 \%$, the number of effective companies 9 (90\%), For 2016, the average efficiency score is $97.7 \%$, the number of effective companies is $8(80 \%)$, For 2017 , the average efficiency score is $95.2 \%$ and the number of effective companies is $8(80 \%)$. The year 2015 is the year in which the highest number of active companies (9). The year in which the average efficiency scores of the companies is highest $(99.1 \%)$ is 2015 .

\section{CONCLUSION}

We can suggest that the companies with the highest performance in the DEA activity scores of the 10 companies included in the scope of the study for the period from 2011 to 2017 are Turistik Air Transport and Reysaş Logistics companies, while the companies with the lowest performance are Ekol Logistics and Omsan Logistics.

Concerning the variables of input (total assets, equity, number of employees) and output (net sales, profit before interest and tax, amount of exports) employed in the study, the companies should decrease or increase the number of employees in order to increase net sales, profit before interest and tax amount and export amount, examine their total assets and increase in equity. In case of a decrease, improvements are required. It is anticipated that ineffective companies can become effective when they reduce the number of employees, equity and total assets by taking advantage of the density of active companies.

The point that should be taken into consideration while evaluating the results is that the study is valid only for the data set of 2011-2017 and does not reflect the whole of Logistics companies. Another issue that should be taken into account regarding the results of the models included in the analysis is the relative efficiency measurement of the firms. The fact that any firm is considered effective as a result of the analysis indicates that it is more effective than other firms, as only the input and output values included in the analysis are taken as basis. 
Depending on the purpose of the study, input-output variables can be changed or new variables can be included in the study. When these situations are in question, the effectiveness values of the companies included in the study may come up with different results. In future studies, different performance evaluation studies can be conducted for logistics companies by using different variables and data sets from different years.

\section{TÜRKIYY'DEKİ LOJISTIKK FİRMALARIN FİNANSAL PERFORMANSLARININ DEĞERLENDİIILMESİ: VERİ ZARFLAMA ANALIZİ YAKLAŞIMI}

\section{GIRISŞ}

Yüksek rekabet koşullarının hakim olduğu günümüz küresel dünyasında firmaların sosyal, beşeri ve finansal kaynaklarını israf etmeden, verimli bir şekilde kullanma zorunlulukları bulunmaktadır. Firmaların gelişen dünya ekonomisinde, artan taleplere yönelik rekabet edebilirlik düzeylerini arttırmaları için hem gelişen teknolojiye göre kendilerini geliştirmeleri, hem de finansal yönden başarıya ulaşmaları gerekmektedir.

Firmalarda finansal performans ölçümü, firmaların yer aldıkları sektörde faaliyetlerini devam ettirebilmeleri, finansal başarı düzeyinin belirlenmesi, firma hedeflerinin gerçekleşip gerçekleşmediğinin öğrenilmesi, firmanın gelecek planlarının doğru bir şekilde belirlenebilmesi nedenlerinden dolayı önemli olmaktadır.

Türkiye hem dünyadaki stratejik konumu, hem genç nüfusun fazla olması, hem de son dönemlerde lojistik sektörüne yönelik yapılan yatırımlar ile dünyada kendine önemli bir yer edinmiş durumdadır. Ekonomideki temel hizmet sektörlerinin başında gelen Lojistik sektörünün, bir ülkenin ticari ve imalat faaliyetleri için önemi oldukça ehemmiyetlidir (Gökalp, 2014: 214). Bu sebeple, Türkiye'deki Lojistik sektöründe yer alan firmaların finansal performans değerlendirilmesinin yapılması önemli olmaktadır. Birçok firmanın daha fazla etkinlik, daha fazla müşteri odaklılık, daha fazla esneklik, maliyetlerin azaltılarak süreçlerde iyileştirme yapılması gibi benzer hedefler oluşturduğunu söylemek mümkündür. Ancak firmalar belirlenen hedeflerin ne ölçüde karşılandığını ölçemiyorlarsa bu hedeflerin gerçekleşmesi zorlaşmaktadır. Performans ölçümü, rekabet avantajı ve farklılaşma elde etmek isteyen firmalar için önemli olmakta, ancak bu süreçte başarılı bir performans ölçümü için basit, sürekli ve verimli olması gereken bir araçtır (Alfaro vd., 2007: 641).

Yoğun rekabet ortamının yaşandığg günümüzde, firmalar mevcut kaynaklarını en iyi şekilde değerlendirmeli ve belirlenen hedeflere ulaşıp ulaşmadıklarını görebilmeleri için periyodik aralıklarla performans değerlendirme çalışmaları gerçekleştirmelidirler. Firmalar arası stratejik performans ölçümü yapmak için aynı sektörde faaliyette bulunan firmaların bir birleri ile karşılaştırılması ve kıyaslanması gerekliliği vardır. 
Performans genel olarak önceden belirlenen bir amaca yönelik oluşturulmuş planlar çerçevesinde varılan hedef olarak tanımlanmaktadır (Gencer, 2006: 6). Performans ölçümü, kurumun amaçlarının neler olduğu, insan gücü potansiyelinin neler olduğunu, elindeki fiziki ve mali kaynakları hangi yöntemin ve tekniklerin geliştirilmesiyle amaçladığı hedeflere yönelik uyguladığı, yapılan çalışmalar sayesinde elde edilen mal ve hizmetlerin, hedeflenen amaçların direkt olarak elde edilmesindeki tesirleri ile diğer yan amaçlara ulaşmasındaki geniş ve dolaylı etkilerin değerlendirilmesi olarak tanımlanır (Yeşilyurt, 2003: 15).

\subsection{Literatür}

Chandra, Cooper, Li ve Rahman (1998), 1994 yılında Kanada da faaliyette bulunan 29 tekstil firmasının finansal performans analizini VZA yöntemi vasıtasıyla gerçekleştirmişılerdir. Sonuç olarak, 8 firma etkin olarak nitelendirilmiştir. Diğer etkin olmayan firmaların etkin olarak faaliyette bulunmaları için firma yapısında, stratejilerinde ve kapasite planlarında ciddi iyileştirmeler yapmaları gerektiği sonucuna varılmıştır. Minwir Al-Shammari (1999), 1995 yılında Ürdün'deki Amman Finans Borsasında faaliyette bulunan imalat sanayi sektöründeki 55 firmanın etkinlik ölçümünü gerçekleştirmişstir. Yapılan çalışmada çıktı yönlü BCC modeli kullanılmıştır. Sonuç olarak, etkin olan firma sayısı 12, bu firmaların ortalama etkinlik skoru ise $\% 54,7$ olarak bulunmuştur.

Bakırcı (2006), Türkiye'deki otomotiv sanayisindeki 13 firmanın finansal etkinliğini VZA yöntemi ile ölçmüştür. Yapılan çalışmada CCR ve BCC modeli kullanılmıştır. Yapılan çalışmada CCR ve BCC modeli kullanılmıştır. Bu çalışmaya benzer olan, Ertuğrul ve Işık (2008), kendi çalışmalarında küçük ölçekli firmaların diğer firmalara göre daha etkin oldukları sonucuna ulaşılmıştır. VZA yöntemini kullanarak metal ana sanayiindeki 13 firmanın 2003-2007 dönemleri arasındaki mali tablolarına dayalı etkinlik ölçümünü gerçekleştirmişlerdir. Çalışmada CCR modeli kullanılmıştır. Sonuç olarak 2003 yılında 4 firmanın etkin olduğu, 2004 yılında sadece 1 firmanın etkin olduğu, 2005 yılında 5 firmanın etkin olduğu, 2006 ve 2007 yılında ise toplam 2 firmanın etkin olduğu gözlemlenmiştir.

Kaya, Öztürk ve Özer (2010), Metal Eşya, Makine ve Gereç Yapım sektöründeki 25 firmanın 2008 yılının 4 dönemine ait finansal tablolarından yararlanarak VZA yöntemi vasıtasıyla performans karşılaştırmasını yapmışlardır. Analiz çıktı yönlü CCR VZA modeli kullanılarak gerçekleştirilmiştir. Analiz sonucunda 4 dönemde toplam 5 firmanın etkin olduğu gözlemlenmiştir. Bir diğer çalışmada Cenger (2011), Çimento sektöründe 1999-2003 dönemine ait finansal tablolarından yararlanarak 12 firmanın etkinlik ölçümünü VZA yöntemiyle gerçekleştirmiştir. Analiz sonucunda firmalardan 9 tanesinin etkin olduğu ve ortalama etkinlik değerinin ise $\% 75$ oranında olduğu belirtilmiştir. 


\section{YÖNTEM}

Non-parametrik yöntemler içinde yer alan VZA, birden fazla girdi-çıktının var olması ve bunların ölçü birimlerinin farklı olduğu durumlarda, karar birimlerinin göreli performansını ölçen doğrusal programlama kökenli bir tekniktir. VZA'da temel varsayım, etkinliği ölçülecek olan tüm işletmelerin benzer stratejik hedeflerinin var olması ve aynı türden girdilerin kullanılıp aynı türden çıktıların üretilmesidir (Oruç, 2008: 11). Birden fazla girdinin kullanılarak birden fazla çıktının olduğu durumlarda, önceden belirlenen her hangi bir analitik üretim fonksiyonu varlığının öngörülmesine ihtiyaç duymadan ölçüm yapabilmesi, yöntemin getirdiği en önemli yeniliktir. Ayrıca girdi ve çıktıların ölçüm birimlerinden bağımsız olması firmaların değişik boyutlarının ölçülebilmesini mümkün kılmaktadır (Yalçıner vd., 2004: 5).

Bu çalışmada 2011-2017 yılları arasında ilgili girdi-çıktı verilerine ulaşılabilen, Türkiyede Depolama, Taşımacılık ve Lojistik hizmetler sektöründe yer alan benzer çıktılar üreten ve homojen yapıdaki 10 firma dâhil edilerek analiz yapılmıştır. Çalışmada değerlendirmeye alınan lojistik firmalarına VZA uygulaması yapılarak firmaların etkinlik düzeyleri belirlenmiş ve etkin olmayan firmalar için referans kümesi oluşturularak etkin olabilmeleri için izlenecek yollar açıklanmıştır.

\section{BULGULAR}

Elde edilen bulgular incelendiğinde, VZA CCR-I modeli sonuçlarına göre lojistik firmaların; 2011 yılında ortalama etkinlik skoru \%75,8, etkin firma sayıs1 4 (\%40) adet, 2012 yılında ortalama etkinlik skoru \%87,3, etkin firma sayısı 6 (\%60) adet, 2013 yılında ortalama etkinlik skoru \%70,2, etkin firma sayıs1 3 (\%30) adet, 2014 y1lında ortalama etkinlik skoru \%73,7, etkin firma sayıs 5 (\%50) adet, 2015 y1lında ortalama etkinlik skoru \%89, 1, etkin firma say1s1 7 (\%70) adet, 2016 yılında ortalama etkinlik skoru \%89,2, etkin firma say1s1 6(\%60) adet, 2017 yılında ise ortalama etkinlik skoru \%81,2, etkin firma sayısı 4 (\%40) adet bulunmuştur. 2015 yılı en fazla etkin firma sayısının (7) olduğu yıldır. Firmaların ortalama etkinlik skorlarının en yüksek bulunduğu $(\% 89,2)$ yıl ise 2016 yılıdır.

VZA BCC-I modeli incelendiğinde 2011-2017 yıllarında lojistik firmaların etkinlik değerleri CCR-I modeline göre hem etkin olan firma sayısı, hem de ortalama etkinlik skoru açısından yüksek sonuçlar elde edildiği görülmektedir. VZA BCC-I modeline göre 2011 yılında lojistik firmaların ortalama etkinlik skoru \%90,1, etkin firma sayıs $8(\% 80)$ adet, 2012 yılında ortalama etkinlik skoru \%92,5, etkin firma sayıs 7(\%70) adet, 2013 yılında ortalama etkinlik skoru \%90,6, etkin firma sayıs1 7(\%70) adet, 2014 y1lında ortalama etkinlik skoru \%94, etkin firma sayıs $7(\% 70)$ adet, 2015 yılında ortalama etkinlik skoru $\% 99,1$, etkin firma sayıs $9(\% 90)$ adet, 2016 y1lında ortalama etkinlik skoru \%97,7, etkin firma sayıs $8(\% 80)$ adet, 2017 yılında ise ortalama etkinlik skoru \%95,2 ve etkin firma sayısı 8 (\%80) adet bulunmuş- 
tur. 2015 yılı en fazla etkin firma sayısının (9 adet) olduğu yıldır. Firmaların ortalama etkinlik skorlarının en yüksek bulunduğu $(\% 99,1)$ yıl ise 2015 yılı olmaktadır.

\section{TARTIŞMA}

Son zamanlarda değişen ekonomik koşullar göz önünde bulundurulduğunda, firmaların finansal istikrarı yeterince sağlayamadıkları görülmekte ve bu durumdan dolayı finansal başarısızlık yaşadıklarını söylemek mümkündür. Bu nedenle, firmaların finansal yapısı bozulmadan, kriz durumuna girmeden önce, faaliyette bulundukları çevreyi iyi tanımalı, bazı kavramlara önem vermeleri ve firmanın finansal yapısı ile ilgili sonuçları gösteren analizleri yapmaları gerekmektedir. Firma performansı işletme dünyasında önemli bir paya sahip olmaktadır. Bu durumda, firmalar gösterdiği performans düzeyine göre var olduğu sektörde faaliyetlerini devam ettireceklerdir veya gereken rekabet koşullarını sağlayamayıp faaliyetlerini sonlandıracaklardır.

Çalışmada belirlenen girdi (toplam aktif, özkaynaklar, çalışan sayısı) ve çıktı (net satışlar, fvök, ihracat miktarı) değişkenlerinde firmaların belirli düzeyde net satışlarını, fvök tutarını ve ihracat miktarını artırması için çalışan sayısının azaltılması veya artırılması, toplam aktiflerinin incelenmesi ve özkaynaktaki artış veya azalış durumunda iyileştirmeler yapılması gerekmektedir. Etkin olmayan firmalar etkin firmaların yoğunluk derecesinden yararlanarak çalışan sayısı, özkaynak ve toplam aktiflerini azalttıklarında etkin duruma gelebilecekleri öngörülmektedir.

\section{SONUÇ}

2011-2017 yıllarında çalışma kapsamına alınan 10 firmadan VZA etkinlik skorlarında genel olarak en yüksek performans gösteren firmaların Turistik Hava Taşımacılık ve Reysaş Taşımacılık firmalarının olduğu görülmekte, en az performans gösteren firmalar ise Ekol Lojistik ve Omsan Lojistik firmaları olmuştur.

Sonuçlar değerlendirilirken göz önünde bulundurulması gereken husus, çalışmanın sadece 2011-2017 yıllarına ait veri seti için geçerli olduğu ve Lojistik firmaların bütününü yansıtmadığıdır. Analize dâhil edilen modellerin sonuçlarıyla ilgili dikkate alınılması gereken bir diğer husus, çalışmadaki firmaların göreli etkinlik ölçümünün yapılmasıdır. Analiz sonucunda herhangi bir firmanın etkin olarak nitelendirilmesi, sadece analize dâhil edilen girdi çıktı değerleri esas alındığından diğer firmalara göre etkin durumda olduğunu gösterir. Yapılan çalışmanın amacına göre girdi-çıktı değişkenleri değiştirilebilir veya yeni değişkenler çalışmaya dâhil edilebilir. Bu durumlar söz konusu olduğunda, çalışma kapsamına alınan firmaların etkinlik değerleri farklı sonuçlarla karşımıza çıkabilmektedir. 


\section{REFERENCES}

Alfaro, J; Ortiz, A; Poler, R. (2007). Performance Measurement System for Business Processes, Production Planning Control,. 18(8), 641-654.

Aydemir, Canan Z. (2002). Bölgesel Rekabet Edebilirlik Kapsamında İllerin Kaynak Kullanım Görece Verimlilikleri: Veri Zarflama Analizi Uygulaması, DPT-Uzmanlık Tezleri, Ankara.

Bakırc1, Fehim (2006). Sektörel Bazda Bir Etkinlik Ölçümü: VZA İle Bir Analiz. İktisadi ve Ídari bilimler Dergisi, 20(2), 199-217.

Bakırc1, Fehim (2006). Üretimde Etkinlik ve Verimlilik Ölçümü, Veri Zarflama Analizi, Teori ve Uygulama. Ankara: Atlas Yayınları.

Barutçu, Yasemin (2013). Etkinlik ve Verimlilik Ölçüm Yöntemleri Üzerine Bir Yazılım Uygulaması, Yüksek Lisans Tezi, Gazi Üniversitesi, Sosyal Bilimler Enstitüsü, Ankara.

Baysal, Mehmet E; Uygur, Mehmet; Toklu, Bilal (2004). Veri Zarflama Analizi ile TCDD Limanlarında Bir Etkinlik Ölçümü Çalışması. Gazi Üniversitesi Mühendislik Mimarlık Fakültesi Dergisi, 19(4), 437-442.

Cenger, Hatice (2011). İMKB'de İşlem Gören Çimento Şirketlerinin Performanslarının Ölçülmesinde Veri Zarflama Analizi Yaklaşımı. Atatürk Üniversitesi İktisadi ve İdari Bilimler Dergisi, 25(4), 31-44.

Chen, Yao; Ali, Iqbal, A. (2002). Continuous Optimization Output-Input Ratio Analysis. European Journal of Operational Research, 142, 476-479.

Coelli, Tim; Prasada D.S. Rao; George E. Battase. (2001). An Introduction To Efficiency and Productivity Analysis. USA: Kluwer Academic Publishers, Fifth Printing 2001.

Depren, Özer (2008). Veri Zarflama Analizi ve Bir Uygulama.Yıldız Teknik Üniversitesi, Fen Bilimleri Enstitüsü, Yayımlanmamış Yüksek Lisans Tez, İstanbuli.

Dinçer, Erdal (2008). Veri Zarflama Analizinde Malmquist Endeksiyle Toplam Faktör Verimliliği Değişiminin İncelenmesi Ve İMKB Üzerine Bir Uygulama. Marmara Üniversitesi, IIIBF Dergisi, 25(2), 825-845.

Ertuğrul, İrfan; IŞIK Tuş. A. (2008). İşletmelerin VZA ile mali tablolarına dayalı etkinlik ölçümü: Metal Ana Sanayiinde Bir Uygulama. Afyon Kocatepe Üniversitesi IIBFF Dergisi, 10(1), 201-207.

Fortune 500 Türkiye. http://www.fotuneturkey.com/fortune500 (Erişim Tarihi: 20.05.2020)

Gencer, Hatice (2006). Genel İşletme Performansı ve Finansal Performans İlişkisi - Çimento Sektöründe Bir Uygulama, Yayımlanmamış Yüksek Lisans Tezi, Gaziantep Üniversitesi, Sosyal Bilimler Enstitüsü, Gaziantep.

Gökalp, Füsun (2014). Lojistik Hizmeti Sağlayan İşletmelerde Mali Performansı Etkileyen Performans Ölçütlerinin Belirlenmesi. Girişimcilik ve Kalkınma Dergisi, 9(1), 211-231. 
Kaya, Abdulkadir; Öztürk, Meryem; Özer, Ali. (2010). Metal Eşya, Makine ve Gereç Yapım Sektördeki İşletmelerin Veri Zarflama Analizi ile Etkinlik Ölçümü. Atatürk Üniversitesi İktisadi ve İdari Bilimler Dergisi,, 24(1), 129-147.

Kaynar, Oğuz (2004). Veri Zarflama Analizi (Data Envelopment Analysis- DEA) ve Göreceli Etkinlik Analizi Üzerine Bir Uygulama, Cumhuriyet Üniversitesi Sosyal Bilimler Enstitüsü, Yayımlanmamış Doktora Tezi, Sivas.

Köksal, Can D. (2001). Veri Zarflama Analizi İle Bankacılıkta Göreceli Verimlilik Ölçümü,Süleyman Demirel Üniversitesi, Sosyal Bilimler Enstitüsü, Yayımlanmamış Doktora Tezi, Isparta.

Milind, Sathye (2003). Efficiency of Banks in a Developing Economy: The Case of India. European Journal of Operational Resarch, 148, 662-671.

Minwir, Al-Shammari (1999). Optimization Modeling for Estimating and Enhancing Relative Efficiency with Application to Industrial Companies. European Journal of Operational Research, 115(3), 488-496.

Oruç, Kenan O. (2008). Veri Zarflama Analizi İle Bulanık Ortamda Etkinlik Ölçümleri Ve Üniversitelerde Bir Uygulama,Süleyman Demirel Üniversitesi, Sosyal Bilimler Enstitüsü,Yayımlanmamış Doktora Tezi, Isparta.

Pankaj, Chandra; William, W. Cooper, \& Shanling Li; Atiqur, Rahman. (1998). Using DEA to Evaluate 29 Canadian Textile Companies - Considering Returns to Scale. International Journal of Production Economics, 115(3), 129-141.

Paradi, Joseph C; Schaffnit, Claire. (2004). Commercial Branch Performance Evulation and Results Communication in a Canadian Bank- a DEA Application. European Journal of Operational Resarch, 156, 719-735.

Wheelock, C.David; Wilson, W.Paul. (995). Evaluating the Effieciency of Commerical Banks: Does Our View of What Banks to Matter? Business Source-Magazine,Federal Resarch Bank of St. Louis Review, 39-52.

Yalçıner, Kürşat; Atan, Murat; Kayacan, Murad; Boztosun, Derviş. (2004). İMKB 30Endeksinde Etkinlik Analizi ( Veri Zarflama Analizi- VZA) ile Hisse Senedi Seçimi. 1.Uluslararası Manas Üniversitesi Ekonomi Konferansı. Bişkek-Kazakistan, 23-24 Eylül, s.530.

Yeşilyurt, Cavit (2003). Matematik Programlama Tabanlı Etkinlik Ölçüm Yöntemlerinden Veri Zarflama Analizi İle Orta Öğretimde Etkinlik Ölçümü. Doktora Tezi, Cumhuriyet Üniversitesi, Sosyal Bilimler Enstitüsü, Sivas. 


\begin{tabular}{|c|c|c|}
\hline $\begin{array}{c}\text { KATKI ORANI / } \\
\text { CONTRIBUTION RATE }\end{array}$ & AÇIKLAMA / EXPLANATION & $\begin{array}{l}\text { KATKIDA BULUNANLAR / } \\
\text { CONTRIBUTORS }\end{array}$ \\
\hline $\begin{array}{c}\text { Fikir veya Kavram / Idea or } \\
\text { Notion }\end{array}$ & $\begin{array}{c}\text { Araştırma hipotezini veya fikrini } \\
\text { oluşturmak / Form the research } \\
\text { hypothesis or idea }\end{array}$ & $\begin{array}{c}\text { Elgün ALIYEV } \\
\text { Merve ERTOK ONURLU }\end{array}$ \\
\hline Tasarım / Design & $\begin{array}{c}\text { Yöntemi, ölçeği ve deseni tasarlamak } \\
\text { / Designing method, scale and } \\
\text { pattern }\end{array}$ & $\begin{array}{c}\text { Elgün ALIYEV } \\
\text { Merve ERTOK ONURLU }\end{array}$ \\
\hline $\begin{array}{l}\text { Veri Toplama ve İşleme / Data } \\
\text { Collecting and Processing }\end{array}$ & $\begin{array}{l}\text { Verileri toplamak, düzenlenmek ve } \\
\text { raporlamak / Collecting, organizing } \\
\text { and reporting data }\end{array}$ & $\begin{array}{c}\text { Elgün ALIYYEV } \\
\text { Merve ERTOK ONURLU }\end{array}$ \\
\hline $\begin{array}{c}\text { Tartışma ve Yorum / Discussion } \\
\text { and Interpretation }\end{array}$ & $\begin{array}{l}\text { Bulguların değerlendirilmesinde ve } \\
\text { sonuçlandırılmasında sorumluluk } \\
\text { almak / Taking responsibility in } \\
\text { evaluating and finalizing the findings }\end{array}$ & $\begin{array}{c}\text { Elgün ALIYYEV } \\
\text { Merve ERTOK ONURLU }\end{array}$ \\
\hline $\begin{array}{c}\text { Literatür Taramas1 / Literature } \\
\text { Review }\end{array}$ & $\begin{array}{l}\text { Çalışma için gerekli literatürü } \\
\text { taramak / Review the literature } \\
\text { required for the study }\end{array}$ & $\begin{array}{c}\text { Elgün ALIYEV } \\
\text { Merve ERTOK ONURLU }\end{array}$ \\
\hline
\end{tabular}

